\title{
Annelations of cyclic $\beta$-cyanoketones in the synthesis of functionalized polycyclic compounds and steroids
}

\author{
Arkady Sobolev, ${ }^{\text {a, b }}$ Martin Vos, ${ }^{a}$ Han T. Zuilhof, ${ }^{a}$ Florence C.E. Sarabèr, ${ }^{\text {a }}$ \\ Ben J.M. Jansen, ${ }^{a}$ and Aede de Groot ${ }^{\mathrm{a} *}$ \\ a) Laboratory of Organic Chemistry, Wageningen University, Dreijenplein 8, \\ 6703 HB Wageningen, The Netherlands \\ b) Latvian Institute of Organic Synthesis, Aizkraukles 21, Riga, LV-1006, Latvia \\ E-mail: Aede.deGroot@wur.nl
}

\begin{abstract}
Cyclic $\beta$-cyano ketones like cyanocarvone and 3-cyano-2-methylcyclopentanone can be annelated in high yields with methyl vinyl ketone, ethyl vinyl ketone and 6(3methoxyphenyl)hex-1-en-3-one to cyano-substituted decalones and indanones. Computational studies at the B3LYP/6-31+G(d,p)//B3LYP/6-31G(d,p) level of theory show that thermodynamic rather than kinetic factors can explain the high yields. The annelated products are suitable intermediates for the synthesis of isoprenoid, steroid and homo steroid skeletons.
\end{abstract}

Keywords: Annelation, $\beta$-cyanoketones, carvone, D homo steroid synthesis

\section{Introduction}

Robinson annelation of cycloalkanone enolates is an established procedure for the synthesis of functionalized polycyclic compounds. The yields in these annelations with simple alkyl vinyl ketones vary from $30 \%$ to $85 \%$, dependent on the stability against polymerization of the enone, the steric requirements of the cycloalkanone and the use of protic or aprotic reaction conditions. Usually the yields and the stereoselectivity drop dramatically when higher substituted cycloalkanones have to be annelated. A good solution for this problem has been found by using Lewis acid catalysed Michael type additions ${ }^{1}$.

In the past also good results have been obtained in annelations with cycloalkanones bearing electron withdrawing $\alpha$ substituents like formyl, ester or cyano, or with cyclic $\beta$-diketones. When a functionalized angular substitutent is present in the (natural) product that has to be synthesized, annelations of $\alpha$-cyano ketones give good results ${ }^{2}$. The $\alpha$-cyano group enhances the acidity of the $\alpha$ proton considerably with a minimum of extra steric hindrance. Also possible sidereactions, which may occur by condensation reactions with the $\alpha$-formyl or ester groups, are not observed 
with the cyano group. Annelations of cyclic $\beta$-diketones also procede in good yields and are broadly applied when a functional group in ring B is necessary or convenient in a total synthesis.

An extension of the above mentioned synthetic possibilities in the synthesis of polycyclic compounds may be provided by annelations of $\beta$-cyano ketones, especially when both an angular substituent and a functional group in ring B are desired. Only a few examples of annelations of $\beta$-cyano ketones have been reported in the literature. ${ }^{3-6}$ In our group we have obtained very good results with the annelation of $\beta$-cyanocarvone 6 with methyl vinyl ketone, which afforded the corresponding cyano decalone $\mathbf{1 3}$ in $84 \%$ yield in two easy steps. ${ }^{7}$ An additional advantage is that the starting $\beta$-cyano ketones usually can be obtained easily by 1,4 -addition of cyanide to the corresponding $\alpha, \beta$-unsaturated ketones. We now like to report on our results with the annelation of the cyclic $\beta$-cyano ketones 6 and 7 with some useful enones like 8, 9 and 10 (Scheme 1), leading to cyano-substituted decalones and indanones, which have potential as intermediate for the synthesis of polycyclic isoprenoid, steroid and D-homo steroid skeletons.
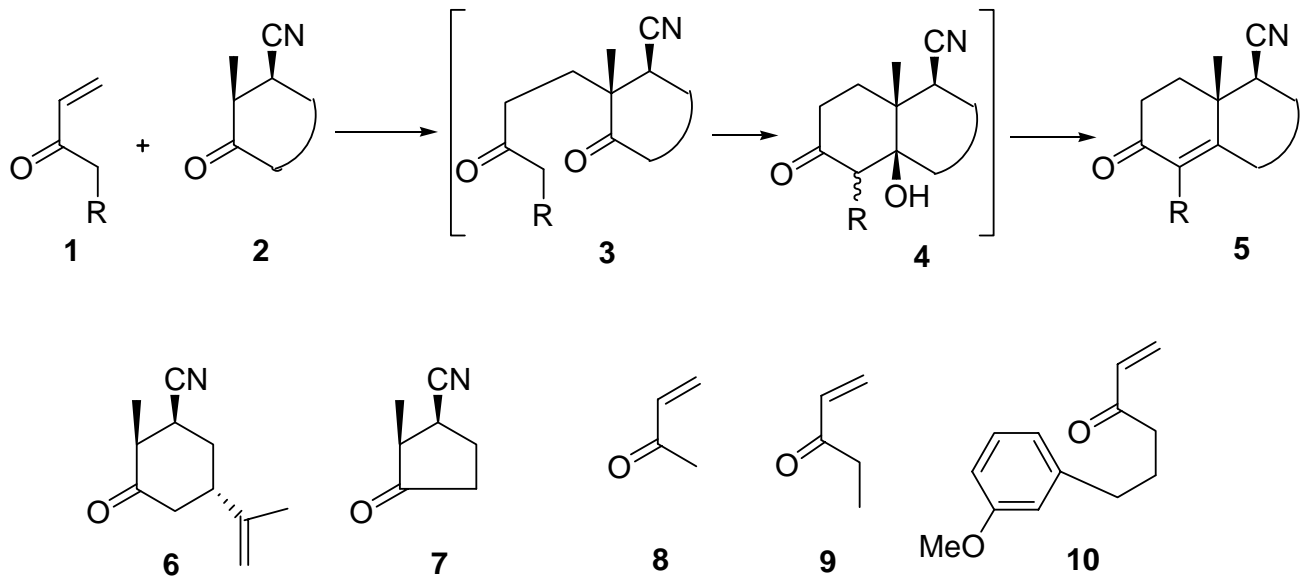

Scheme 1. General scheme for the annelation of cyclic $\beta$-cyanoketones.

\section{Results and Discussion}

The annelation of cyanocarvone $\mathbf{6}$ with methyl vinyl ketone $\mathbf{8}$ under protic conditions using $\mathrm{NaOCH}_{3}$ in $\mathrm{CH}_{3} \mathrm{OH}$, proceeds in a high $90 \%$ yield to a pure crystalline ketol 11. This ketol can be dehydrated in over $90 \%$ yield to the corresponding enone 13 . When a similar reaction of cyanocarvone was tried with ethyl vinyl ketone 9, the addition of methanol to the enone was observed as the main reaction and only little ketol was obtained. A much better $74 \%$ yield of ketol 12 could be achieved under aprotic conditions with $\mathrm{KOtBu}$ in diethyl ether (Scheme 2). This is a high yield for a $\beta$-substituted ketone and comparable with yields obtained in the annelation of $\beta$-unsubstituted ketones ${ }^{8}$ and $\beta$-diketones. ${ }^{9}$ Dehydration of this intermediate ketol to enone $\mathbf{1 4}$ could be achieved easily with $p-\mathrm{TsOH}$ in toluene in $81 \%$ yield. 


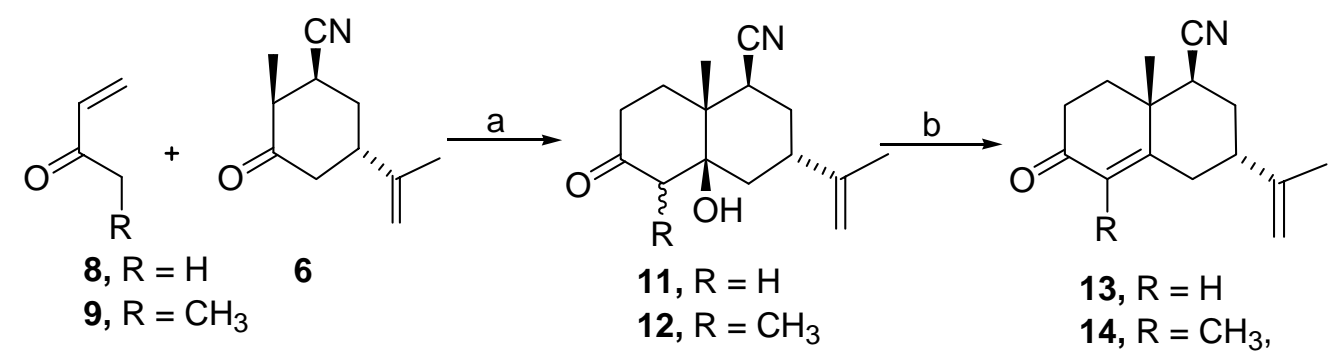

Scheme 2. Annelations of cyanocarvone. a, $\mathrm{NaOMe}, \mathrm{MeOH}$ or $\mathrm{KO} t \mathrm{Bu}, \mathrm{Et}_{2} \mathrm{O} ; \mathrm{b}, \mathrm{p}-\mathrm{TsOH}$, toluene.

A good and convenient synthesis of $\mathbf{1 4}$ is important in total syntheses of natural products where a methyl group and a different $\alpha$-substitutent are present at C4. Monomethylation of $\mathbf{1 3}$ is difficult to tune, ${ }^{9}$ in a typical experiment a mixture of $10 \%$ of $\mathbf{1 4}, 40 \%$ of the dimethylated product and $40 \%$ of starting material 13 was obtained. ${ }^{11}$

The enantioselective synthesis of D-homo steroid skeletons from cyanocarvone $\mathbf{6}$ may become possible when this compound could be annelated with 6(3-methoxyphenyl)hex-1en-3one 10. This enone was synthesized according to the method of Smith et al. ${ }^{12}$, and a reaction with cyanocarvone indeed could be achieved again under aprotic conditions with $\mathrm{KOtBu}$ in diethyl ether, giving one ketol 15 in a good 76\% yield (Scheme 3).

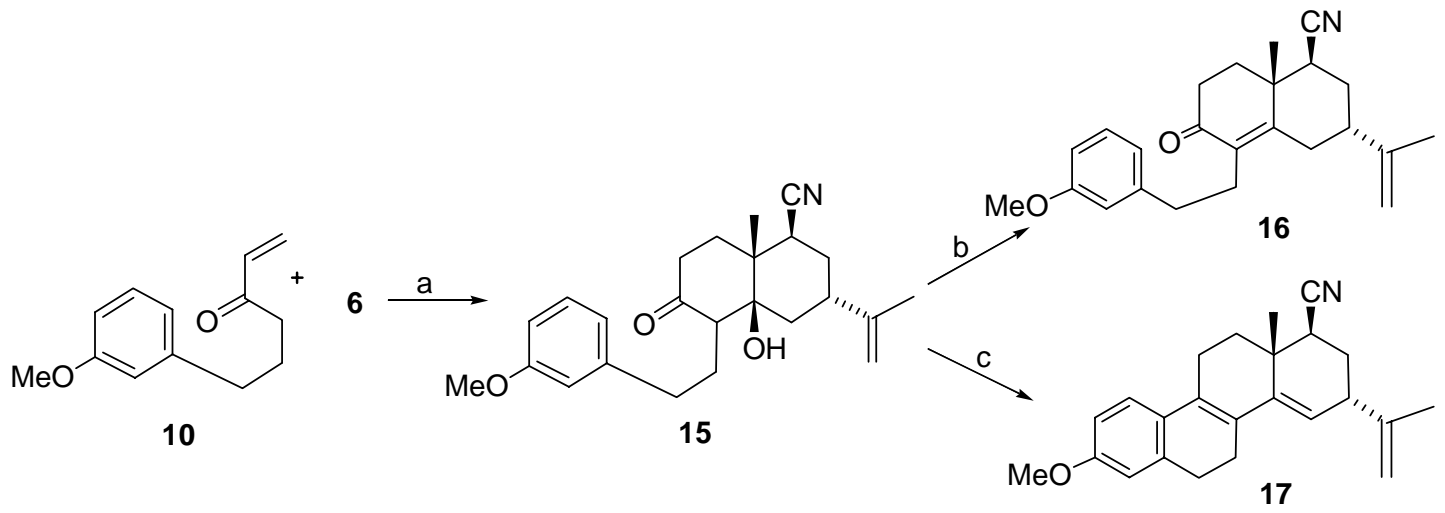

Scheme 3. Synthesis of D homo steroid skeletons. a, $\mathrm{KOtBu}, \mathrm{Et}_{2} \mathrm{O} ; \mathrm{b}, p-\mathrm{TsOH}$, toluene; c, $\mathrm{HClO}_{4}, \mathrm{AcOH}$.

Dehydration of ketol 15 with $p-\mathrm{TsOH}$ in toluene did not give the expected result, and enone 17 was isolated in only $21 \%$ yield, together with $19 \%$ of the starting ketol 15 and a small amount (2\%) of product $\mathbf{1 7}$ in which also ring B was closed. A fair yield of compound $\mathbf{1 7}$ could be obtained in a one pot reaction using $\mathrm{HClO}_{4}$ in $\mathrm{AcOH},{ }^{13}$ which gave this D-homo steroid compound as the only product. This compound proved to be rather unstable, probably because of oxidation to aromatic compounds, and after purification only a $35 \%$ yield of reasonably pure 17 was isolated. 
Addition of potassium cyanide to methylcyclopentenone ${ }^{7}$ gave racemic mixtures of two isomeric 3-cyano-2-methylpentanones 7 in $85 \%$ yield, which could be purified by bulb to bulb distillation. The reaction of this mixture of isomers with methyl vinyl ketone was performed using $\mathrm{NaOMe}$ as base and gave a mixture of stereoisomers of diketone $\mathbf{1 8}$ and ketol $\mathbf{2 0}$ in high yield. This mixture was used without purification in the next dehydration reaction with $p$ - $\mathrm{TsOH}$ in toluene, and after a reaction time of $2 \mathrm{~h}$ the known enone $\mathbf{2 2}$ was obtained in $75 \%$ overall yield as a racemate of a single product, which according to the literature is the $\beta$-cyano compound ${ }^{5}$.

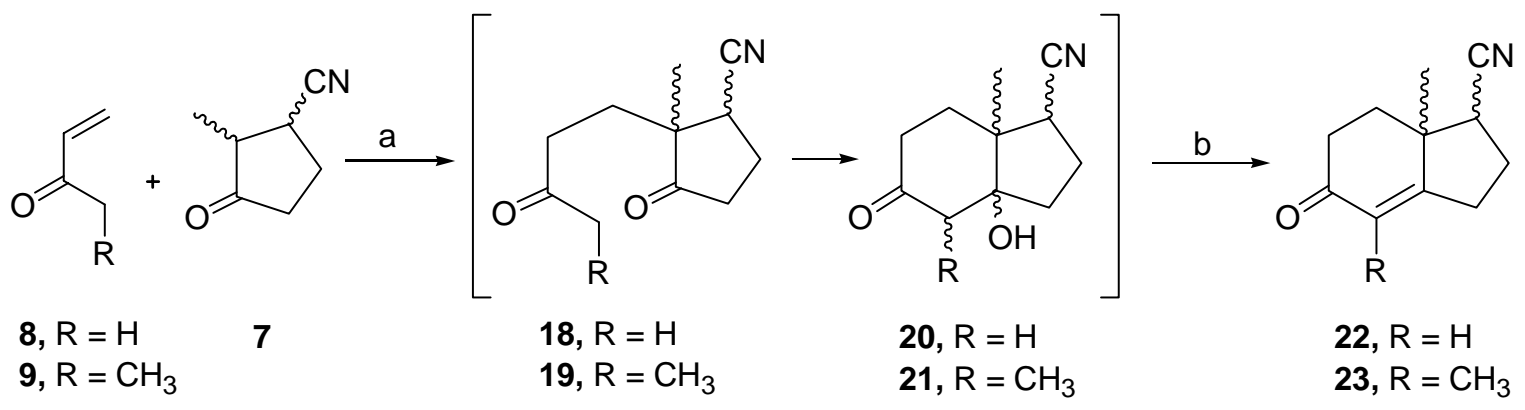

Scheme 4. Annelations of 3-cyano-2-methylcyclopentanones. a, $\mathrm{NaOMe}, \mathrm{MeOH}$ or $\mathrm{KOt} \mathrm{Bu}$, $\mathrm{Et}_{2} \mathrm{O} ; \mathrm{b}, p-\mathrm{TsOH}$, toluene.

The racemic mixture of 3-cyano-2-methylcyclopentenones 7 was also reacted with ethyl vinyl ketone with $\mathrm{KOtBu}$ in ether at $0{ }^{\circ} \mathrm{C}$, giving a complex mixture of ketols 21 and enones 23 . Under these aprotic strongly basic conditions, none of the diketones 19 could be detected, because cyclisation and even partly dehydration take place under these reaction conditions. The mixture of $\mathbf{2 1}$ and $\mathbf{2 3}$ was used in the next step without purification and complete dehydration could be accomplished again by using $p$-TsOH in refluxing toluene. A 2:1 mixture of the racemates of two isomers of $\mathbf{2 3}$ was obtained in $70 \%$ overall yield, which could be separated by column chromatography on silica gel. It was assumed that also in this case the $\beta$-cyano compound was obtained as the major isomer.

The relatively high yields in the annelations of the $\beta$-cyano ketones is related to the ease and selectivity of formation of the anions formed after deprotonation. Computational studies at the B3LYP/6-31+G(d,p)//B3LYP/6-31G(d,p) level of theory ${ }^{14}$ show that the presence of a $\beta$-cyano moiety yields a relatively more stable anion. In comparison with a $\beta$-methyl or a $\beta$-hydrogen moiety this stabilization is around $12-13 \mathrm{kcal} / \mathrm{mol}$, and this difference is not significantly influenced by the nature of the $\alpha$-substituent (hydrogen or methyl). This ease of formation of the anions also improves the selectivity of the anion formation. In ketones with a $\beta$-methyl group both $\alpha$-sites of the carbonyl group are about equally easy to deprotonate, which thus yields a mixture of anions and an overall decrease of selectivity in products. However, in the presence of a $\beta$-cyano group the $\alpha$-site in between the carbonyl and $\beta$-cyano moiety is so much easier to deprotonate than the other $\alpha$-site, that effectively only one anion will be formed, with a concomitant increase of the selectivity and yield of desired products. The extra stabilization of 
the anion by the $\beta$-cyano group is not reflected in the charge distribution of the anions. The natural population charges of the formally negatively charged $\alpha$-carbon atom, which could have been a measure of reactivity differences between the anions of the $\beta$-cyano and $\beta$-methyl compounds, are identical within 0.01 electron. Thermodynamic rather than kinetic factors thus can explain the higher yields in annelations of $\beta$-cyano ketones.

\section{Experimental Section}

General Procedures. ${ }^{1} \mathrm{H}$ NMR spectra $(200 \mathrm{MHz})$ and ${ }^{13} \mathrm{C}$ NMR spectra $(50 \mathrm{MHz})$ were recorded on a Brucker $\mathrm{AC}-\mathrm{E}$ 200. $\mathrm{CDCl}_{3}$ was used as solvent, unless stated otherwise, and chemical shifts are reported in parts per million $(\delta)$ relative to tetramethylsilane $(\delta 0.0)$. MS and HRMS data were obtained with a Finnigan Mat 95 spectrometer. Infrared spectra were obtained on a Brucker Vector 22 FT-IR spectrometer.Column and flash chromatography were performed with ICN silica gel 60 (230-400 mesh), using mixtures of petroleum ether bp 40-60 ${ }^{\circ} \mathrm{C}(\mathrm{PE})$ and ethyl acetate (EtOAc) as eluents, unless reported otherwise.

All computations were performed with Gaussian 98 version A.7. ${ }^{14}$ The structures were optimized at the B3LYP/6-31G(d,p) level of theory, while energies and electronic properties were obtained with inclusion of diffuse functions at the B3LYP/6-31+G(d,p)//B3LYP/6$31 \mathrm{G}(\mathrm{d}, \mathrm{p})$ level of theory. Natural population charges were obtained using the pop=npa command as available via the NBO 3.1 program as implemented in Gaussian 98.

\section{Cis- and trans- 2-methyl-3-oxo-1-cyclopentanecarbonitrile $7^{15}$}

A solution of $3.76 \mathrm{~g}(57.7 \mathrm{mmol})$ of potassium cyanide in $9 \mathrm{ml}$ of water was added dropwise to a stirred solution of $4.00 \mathrm{~g}$ (41.6 mmol) of 2-methyl-2-cyclopenten-1-one in $24 \mathrm{ml}$ of ethanol at 0$5^{\circ} \mathrm{C}$. Then $2.72 \mathrm{ml}(41.6 \mathrm{mmol})$ of glacial $\mathrm{AcOH}$ was added in $2 \mathrm{~h}$. The reaction mixture was stirred for $2 \mathrm{~h}$ at $0-5^{\circ} \mathrm{C}$ and then diluted with water. This mixture was extracted with ethyl acetate $(3 \mathrm{x})$, and the organic solution was washed with water $(2 \mathrm{x})$ and brine and dried over $\mathrm{MgSO}_{4}$. Then the solvent was evaporated to give $4.34 \mathrm{~g}$ ( $85 \%$ ) of crude 7 , which was used for the next transformation without further purification. A small portion was purified by bulb-to bulb distillation for analytical purpose and gave a mixture of cis- and trans-7, of which the spectroscopic data were in accordance with the literature. ${ }^{16}$

6-(3-Methoxy-phenyl)-hex-1-en-3-one (10) was prepared using the method of Douglas et.al.. ${ }^{13}$ The oily product (bp 100-110C/0.01 mm) showed the following spectroscopic characteristics: IR (neat): $3473(\mathrm{OH}), 2237(\mathrm{CN}), 1710(\mathrm{C}=\mathrm{O}) \mathrm{cm}^{-1} .{ }^{1} \mathrm{H} \mathrm{NMR}\left(\mathrm{CDCl}_{3}, 200 \mathrm{MHz}\right): \delta 1.94$ (quintet, $2 \mathrm{H}, J=7.1 \mathrm{~Hz}, \mathrm{CH}_{2} \mathrm{CH}_{2} \mathrm{CH}_{2}$ ), 2.58 (t, 2H, J=7.1 Hz, $\mathrm{CH}_{2}$ ), 2.61 (t, 2H, J=7.1 Hz, $\mathrm{CH}_{2}$ ), 3.77 (s, $\left.3 \mathrm{H}, \mathrm{OCH}_{3}\right), 5.78\left(\mathrm{dd}, 1 \mathrm{H}, J=10.0 \mathrm{~Hz}, J=1.7 \mathrm{~Hz}, \mathrm{CH}=\mathrm{CH}_{2}\right), 6.16(\mathrm{dd}, 1 \mathrm{H}, J=17.6 \mathrm{~Hz}, J=1.6 \mathrm{~Hz}$, $\left.\mathrm{CH}=\mathrm{CH}_{2}\right), 6.30\left(\mathrm{dd}, 1 \mathrm{H}, \mathrm{J}=17.6, \mathrm{~J}=10.0 \mathrm{~Hz}, \mathrm{CH}=\mathrm{CH}_{2}\right), 6.71-6.78(\mathrm{~m}, 3 \mathrm{H}, \mathrm{Ar}), 7.14-7.23(\mathrm{~m}, 1 \mathrm{H}$, Ar); ${ }^{13} \mathrm{C}$ NMR $\left(\mathrm{CDCl}_{3}, 50 \mathrm{MHz}\right): 25.25\left(\mathrm{CH}_{2}\right), 35.12\left(\mathrm{CH}_{2}\right), 38.70\left(\mathrm{CH}_{2}\right), 55.12\left(\mathrm{CH}_{3}\right), 111.27$ $(\mathrm{CH}), 114.21(\mathrm{CH}), 120.90(\mathrm{CH}), 128.05\left(\mathrm{CH}_{2}\right), 129.37(\mathrm{CH}), 136.540(\mathrm{CH}), 143.27(\mathrm{C}), 159.69$ 
(C), 200.59 (C); MS m/z (rel. abund.): 204 (M+, 15), 134 (100), 121 (7), 104 (4), 91 (8), 78 (5), 77 (3) 55 (7); HRMS calcd for $\mathrm{C}_{13} \mathrm{H}_{16} \mathrm{O}_{2}$ 204.1150, found 204.1156.

4a-Hyd roxy-3-isopropenyl-5,8a-dimethyl-6-oxo-decahydro-naphthalene-1-carbonitrile (12). To a stirred solution of $1.77 \mathrm{~g}(10 \mathrm{mmol})$ of cyanocarvone 6 and $1.50 \mathrm{ml}(15.1 \mathrm{mmol})$ of ethyl vinyl ketone $(E V K)$ in $50 \mathrm{ml}$ of dry diethyl ether, $1.12 \mathrm{~g}(10 \mathrm{mmol})$ of potassium tert-butoxide was added at $0{ }^{\circ} \mathrm{C}$. The reaction mixture was stirred for $2.5 \mathrm{~h}$ at $0{ }^{\circ} \mathrm{C}$ and then quenched with 1 $\mathrm{M} \mathrm{HCl}$. The organic layer was washed with water and brine, dried over $\mathrm{MgSO}_{4}$ and the solvent was evaporated. The remaining residue was flash chromatographed on silica gel with PE/EtOAc (75:25 $\rightarrow 50: 50)$ to give $1.83 \mathrm{~g} \mathrm{(70 \% )} \mathrm{of} \mathbf{1 2}$ as a viscous oil. IR (neat): $3477(\mathrm{OH}), 2239(\mathrm{CN})$, $1709(\mathrm{C}=\mathrm{O}) \mathrm{cm}^{-1} .{ }^{1} \mathrm{H}$ NMR $\left(\mathrm{CDCl}_{3}, 200 \mathrm{MHz}\right): \delta 1.03\left(\mathrm{~d}, 3 \mathrm{H}, J=6.7 \mathrm{~Hz}, \mathrm{CH}_{3}\right), 1.4-2.7(\mathrm{~m}, 10$ $\mathrm{H}), 1.58\left(\mathrm{~s}, 3 \mathrm{H}, \mathrm{CH}_{3}\right), 1.69\left(\mathrm{~s}, 3 \mathrm{H}, \mathrm{CH}_{3}\right), 2.88\left(\mathrm{q}, 1 \mathrm{H}, \mathrm{J}=6.7 \mathrm{~Hz}, \mathrm{CHCH}_{3}\right), 4.70\left(\mathrm{~s}, 1 \mathrm{H},=\mathrm{CH}_{2}\right)$, $4.77\left(\mathrm{~s}, 1 \mathrm{H},=\mathrm{CH}_{2}\right) ;{ }^{13} \mathrm{C} \mathrm{NMR}\left(\mathrm{CDCl}_{3}, 50 \mathrm{MHz}\right): 6.20\left(\mathrm{CH}_{3}\right), 19.90\left(\mathrm{CH}_{3}\right), 20.90\left(\mathrm{CH}_{3}\right), 28.74$ $\left(\mathrm{CH}_{2}\right), 31.51\left(\mathrm{CH}_{2}\right), 33.12\left(\mathrm{CH}_{2}\right), 35.67(\mathrm{CH}), 37.12\left(\mathrm{CH}_{2}\right), 37.32(\mathrm{CH}), 39.60(\mathrm{C}), 51.72(\mathrm{CH})$, 77.30 (C), $110.30\left(\mathrm{CH}_{2}\right), 121.81$ (C), 147.19 (C), 209.05 (C). MS m/z (rel. abund.): 261 (M+, 45), 243 (24), 177 (37), 158 (14), 134 (58), 84 (100); HRMS calcd for $\mathrm{C}_{16} \mathrm{H}_{23} \mathrm{NO}_{2}$ 261.1729, found 261.1732 .

\section{3-Isopropenyl-5,8a-dimethyl-6-oxo-1,2,3,4,6,7,8,8a-octahydro-naphthalene-1-carbonitrile}

(14). Ketol $12(0.783 \mathrm{~g}, 3 \mathrm{mmol})$ in $50 \mathrm{ml}$ of toluene was heated to reflux in a Dean-Stark apparatus, and $40 \mathrm{mg}$ of $p-\mathrm{TsOH}$ was added in three portions. After $5 \mathrm{~h}$ of reflux the reaction mixture was cooled to room temperature, washed with sodium bicarbonate solution and water, dried over $\mathrm{MgSO}_{4}$ and the solvent was evaporated. The residue was flash chromatographed on silica gel with PE/EtOAc (70:30) to give $0.59 \mathrm{~g}(81 \%)$ of $\mathbf{1 4}$ as yellow oil. Crystallisation from $t$ BuOMe gave white crystals, 84-86 mp ${ }^{\circ} \mathrm{C}$. IR $\left(\mathrm{CCl}_{4}\right): 2240(\mathrm{CN}), 1674(\mathrm{C}=\mathrm{O}) \mathrm{cm}^{-1} .{ }^{1} \mathrm{H}$ NMR $\left(\mathrm{CDCl}_{3}, 200 \mathrm{MHz}\right): \delta 1.40$ (s, 3H, $\left.\mathrm{CH}_{3}\right), 1.6-2.7(\mathrm{~m}, 9 \mathrm{H}), 1.73\left(\mathrm{~s}, 3 \mathrm{H}, \mathrm{CH}_{3}\right), 1.82\left(\mathrm{~s}, 3 \mathrm{H}, \mathrm{CH}_{3}\right)$, $2.95(\mathrm{~d}, 1 \mathrm{H}, J=16.1 \mathrm{~Hz}, \mathrm{CH}), 4.60\left(\mathrm{~s}, 1 \mathrm{H},=\mathrm{CH}_{2}\right), 4.89\left(\mathrm{~s}, 1 \mathrm{H},=\mathrm{CH}_{2}\right) ;{ }^{13} \mathrm{C} \mathrm{NMR}\left(\mathrm{CDCl}_{3}, 50\right.$ MHz): $\delta 11.31\left(\mathrm{CH}_{3}\right), 19.05\left(\mathrm{CH}_{3}\right), 22.64\left(\mathrm{CH}_{3}\right), 27.07\left(\mathrm{CH}_{2}\right), 30.26\left(\mathrm{CH}_{2}\right), 33.39\left(\mathrm{CH}_{2}\right), 35.58$ $\left(\mathrm{CH}_{2}\right), 36.60(\mathrm{CH}), 37.60(\mathrm{C}), 39.05(\mathrm{CH}), 112.73\left(\mathrm{CH}_{2}\right), 120.29(\mathrm{C}), 131.07(\mathrm{C}), 145.75(\mathrm{C})$, 156.95 (C), 197.15 (C). MS m/z (rel. abund.): 243 (M+, 54), 228 (21), 201 (13), 200 (14), 190 (54), 132 (100), 119 (22); HRMS calcd for $\mathrm{C}_{16} \mathrm{H}_{21} \mathrm{NO} 243.1623$, found 243.1618.

4a-Hydroxy-3-isopropenyl-5-[2-(3-methoxy-phenyl)-ethyl]-8a-methyl-6-oxo-decahydronaphthalene-1-carbonitrile (15). To a stirred solution of $0.584 \mathrm{~g}(3.3 \mathrm{mmol})$ of cyanocarvone 6 and $1.02 \mathrm{~g}(5.0 \mathrm{mmol})$ of 6(3-methoxyphenyl)hex-1-en-3-one (10) in $20 \mathrm{ml}$ of dry diethyl ether, $0.403 \mathrm{~g}(3.6 \mathrm{mmol})$ of potassium tert-butoxide was added at $0{ }^{\circ} \mathrm{C}$. The reaction mixture was stirred at $0{ }^{\circ} \mathrm{C}$ for $2.5 \mathrm{~h}$, and then quenched with $1 \mathrm{M} \mathrm{HCl}$. The organic layer was washed with water and brine, dried over $\mathrm{MgSO}_{4}$ and the solvent was evaporated. The remaining residue was flash chromatographed on silica gel with PE/EtOAc $(1: 3 \rightarrow 1: 1)$ to give $0.955 \mathrm{~g}(76 \%)$ of hydroxyketone 15 as a viscous oil. IR (neat): $3473(\mathrm{OH}), 2237(\mathrm{CN}), 1710(\mathrm{C}=\mathrm{O}) \mathrm{cm}^{-1} .{ }^{1} \mathrm{H}$ NMR $\left(\mathrm{CDCl}_{3}, 200 \mathrm{MHz}\right) \delta 1.00-2.80(\mathrm{~m}, 15 \mathrm{H}), 1.52\left(\mathrm{~s}, 3 \mathrm{H}, \mathrm{CH}_{3}\right), 1.68\left(\mathrm{~s}, 3 \mathrm{H}, \mathrm{CH}_{3}\right), 3.79(\mathrm{~s}, 3 \mathrm{H}$, $\left.\mathrm{CH}_{3}\right), 4.67\left(\mathrm{~s}, 1 \mathrm{H}, \mathrm{CH}_{2}\right), 4.75\left(\mathrm{~s}, 1 \mathrm{H}, \mathrm{CH}_{2}\right), 6.71-6.80(\mathrm{~m}, 3 \mathrm{H}), 7.15-7.26(\mathrm{~m}, 1 \mathrm{H}) ;{ }^{13} \mathrm{C}\left(\mathrm{CDCl}_{3}\right.$, $50 \mathrm{MHz}) \delta 20.04\left(\mathrm{CH}_{3}\right), 20.93\left(\mathrm{CH}_{3}\right), 23.32\left(\mathrm{CH}_{2}\right), 28.78\left(\mathrm{CH}_{2}\right), 31.91\left(\mathrm{CH}_{2}\right), 33.91\left(\mathrm{CH}_{2}\right)$, 
$35.04\left(\mathrm{CH}_{2}\right), 35.66(\mathrm{CH}), 37.30(\mathrm{CH}), 37.85\left(\mathrm{CH}_{2}\right), 39.74(\mathrm{C}), 55.19\left(\mathrm{CH}_{3}\right), 57.01(\mathrm{CH}), 77.92$ (C), $110.38\left(\mathrm{CH}_{2}\right), 111.37(\mathrm{CH}), 114.15(\mathrm{CH}), 120.83(\mathrm{CH}), 121.68(\mathrm{C}), 129.43(\mathrm{CH}), 143.67$ (C), 147.07 (C), 159.70 (C), 208.08 (C). Ms m/z (rel. abund.): 381 (M+24), 363 (26), 260 (13), 243 (10), 229 (14), 228 (10), 134 (100), 122 (19), 121 (17), 83 (13); HRMS calcd for $\mathrm{C}_{24} \mathrm{H}_{31} \mathrm{NO}_{3}$ 381.2304 , found 381.2305 .

\section{3-Isopropenyl-5-[2-(3-methoxy-phenyl)-ethyl]-8a-methyl-6-oxo-1,2,3,4,6,7,8,8a-octahydro-} naphthalene-1-carbonitrile (16). To a stirred solution of $381 \mathrm{mg}$ (1 mmol) of hydroxyketone $\mathbf{1 5}$ in $30 \mathrm{ml}$ of benzene at reflux temperature, $55 \mathrm{mg}$ of $p$-TsOH was added in five portions. The reaction mixture was refluxed for $12 \mathrm{~h}$ using a Dean-Stark apparatus. Then the reaction mixture was washed with a saturated aqueous sodium bicarbonate solution and water, dried over $\mathrm{MgSO}_{4}$ and the solvent was evaporated. The remaining residue was flash chromatographed on silica gel with $\mathrm{PE} /$ EtOAc/pyridine (70:30:1) to give $72 \mathrm{mg}$ (19\%) of unconverted 15, $76 \mathrm{mg}$ (21\%) of enone 16 and $6 \mathrm{mg}$ ( $2 \%$ ) of $\mathbf{1 7}$ (vide infra) as pale yellow oils. The spectroscopic characteristics of 16 are: IR (neat): $2238(\mathrm{CN}), 1666(\mathrm{C}=\mathrm{O}) \mathrm{cm}^{-1} .{ }^{1} \mathrm{H}$ NMR $\left(\mathrm{C}_{6} \mathrm{D}_{6}, 200 \mathrm{MHz}\right) \delta 1.00(\mathrm{~s}, 3 \mathrm{H}$, $\left.\mathrm{CH}_{3}\right), 1.20-1.61\left(\mathrm{~m}, 4 \mathrm{H}, \mathrm{CH}_{2}\right), 1.34\left(\mathrm{~s}, 3 \mathrm{H}, \mathrm{CH}_{3}\right), 1.78-1.87\left(\mathrm{~m}, 2 \mathrm{H}, \mathrm{CH}_{2}\right), 2.10-2.80(\mathrm{~m}, 7 \mathrm{H}$, $\left.\mathrm{CH}_{2}, \mathrm{CH}\right), 3.00-3.15(\mathrm{~m}, 1 \mathrm{H}, \mathrm{CH}), 3.40\left(\mathrm{~s}, 3 \mathrm{H}, \mathrm{CH}_{3}\right), 4.48\left(\mathrm{~s}, 1 \mathrm{H}, \mathrm{CH}_{2}\right), 4.68\left(\mathrm{~s}, 1 \mathrm{H}, \mathrm{CH}_{2}\right), 6.69-$ $6.81(\mathrm{~m}, 3 \mathrm{H}), 7.06-7.15(\mathrm{~m}, 1 \mathrm{H}) ;{ }^{13} \mathrm{C}\left(\mathrm{C}_{6} \mathrm{D}_{6}, 50 \mathrm{MHz}\right) \delta 18.78\left(\mathrm{CH}_{3}\right), 22.20\left(\mathrm{CH}_{3}\right), 26.74\left(\mathrm{CH}_{2}\right)$, $27.85\left(\mathrm{CH}_{2}\right), 29.28\left(\mathrm{CH}_{2}\right), 33.53\left(\mathrm{CH}_{2}\right), 34.82\left(\mathrm{CH}_{2}\right), 35.34\left(\mathrm{CH}_{2}\right), 36.37(\mathrm{CH}), 37.27(\mathrm{C}), 38.58$ $(\mathrm{CH}), 54.50\left(\mathrm{CH}_{3}\right), 111.34(\mathrm{CH}), 112.43\left(\mathrm{CH}_{2}\right), 114.77(\mathrm{CH}), 119.85(\mathrm{C}), 121.22(\mathrm{CH}), 129.32$ (CH), 134.25 (C), 143.37 (C), 145.83 (C), 156.80 (C), 160.03 (C), 195.08 (C). Ms m/z (rel. abund.): 363 (M+100), 242 (15), 228 (53), 134 (6), 122 (51), 121 (41), 91 (18); HRMS calcd for $\mathrm{C}_{24} \mathrm{H}_{29} \mathrm{NO}_{2}, 363.2198$ found 363.2192.

\section{3-Isopropenyl-8-methoxy-12a-methyl-1,2,3,4,4a,5,6,11,12,12a-decahydro-chrysene-1-}

carbonitrile (17). To a stirred solution of $381 \mathrm{mg}(1 \mathrm{mmol})$ of hydroxyketone $\mathbf{1 5}$ in acetic acid $(8 \mathrm{~mL})$ was added $0.077 \mathrm{ml}(0.9 \mathrm{mmol})$ of $70 \% \mathrm{HClO}_{4}$ at $15^{\circ} \mathrm{C}$. The mixture was stirred for $2 \mathrm{~h}$ at $15^{\circ} \mathrm{C}$, and then for $2.5 \mathrm{~h}$ at $30{ }^{\circ} \mathrm{C}$. The now purple solution was diluted with water and extracted with ethyl acetate. The combined organic layers were washed with a saturated sodium bicarbonate solution, brine, dried over $\mathrm{MgSO}_{4}$ and the solvent was evaporated. The remaining residue was flash chromatographed on silica gel with PE/EtOAc/pyridine (15:84:1) to give 120 $\mathrm{mg}(35 \%)$ of 17 as a yellow oil. IR (neat): $2237(\mathrm{CN}) \mathrm{cm}^{-1} .{ }^{1} \mathrm{H} \mathrm{NMR}\left(\mathrm{C}_{6} \mathrm{D}_{6}, 50 \mathrm{MHz}\right) \delta 1.11-2.20$ $(\mathrm{m}, 6 \mathrm{H}) ; 1.17\left(\mathrm{~s}, 3 \mathrm{H}, \mathrm{CH}_{3}\right) ; 1.53\left(\mathrm{~s}, 3 \mathrm{H}, \mathrm{CH}_{3}\right) ; 2.20-2.60(\mathrm{~m}, 6 \mathrm{H}) ; 3.44\left(\mathrm{~s}, 3 \mathrm{H}, \mathrm{CH}_{3}\right) ; 4.60(\mathrm{~s}, 1 \mathrm{H}$, $\left.\mathrm{CH}_{2}\right) ; 4.82\left(\mathrm{~s}, 1 \mathrm{H}, \mathrm{CH}_{2}\right) ; 5.48(\mathrm{~d}, 1 \mathrm{H}, \mathrm{J}=4.8 \mathrm{~Hz}, \mathrm{CH}) ; 6.77-6.82(\mathrm{~m}, 2 \mathrm{H}) ; 7.16-7.20(\mathrm{~m}, 1 \mathrm{H}) .{ }^{13} \mathrm{C}$ $\left(\mathrm{C}_{6} \mathrm{D}_{6}, 50 \mathrm{MHz}\right) \delta 19.02\left(\mathrm{CH}_{3}\right) ; 21.68\left(\mathrm{CH}_{3}\right) ; 22.50\left(\mathrm{CH}_{2}\right) ; 24.10\left(\mathrm{CH}_{2}\right) ; 25.53\left(\mathrm{CH}_{2}\right) ; 28.81$ $\left(\mathrm{CH}_{2}\right) ; 34.57(\mathrm{C}) ; 34.82\left(\mathrm{CH}_{2}\right) ; 35.43(\mathrm{CH}) ; 41.06(\mathrm{CH}) ; 54.55\left(\mathrm{CH}_{3}\right) ; 111.30(\mathrm{CH}) ; 113.06$ $\left(\mathrm{CH}_{2}\right) ; 113.35(\mathrm{CH}) ; 120.62(\mathrm{CH}) ; 120.99(\mathrm{C}) ; 124.39(\mathrm{CH}) ; 127.01(\mathrm{C}) ; 128.70(\mathrm{C}) ; 128.96(\mathrm{C})$; 137.94 (C); 140.63 (C); 146.81 (C); 159.01 (C). Ms m/z (rel. abund.): 345 ( $\left.\mathrm{M}^{+}, 100\right), 343$ (10), 330 (9), 314 (5), 304 (20), 302 (5); HRMS calcd for $\mathrm{C}_{24} \mathrm{H}_{27} \mathrm{NO} 345.2093$ found 345.2090.

7a-Methyl-5-oxo-2,3,5,6,7,7a-hexahydro-1H-indene-1-carbonitrile (22). ${ }^{5}$ To a stirred solution of $1.85 \mathrm{~g}(15 \mathrm{mmol})$ of cyanocyclopentanone 7 and $3.75 \mathrm{ml}(45 \mathrm{mmol})$ of methyl vinyl ketone (MVK) in $30 \mathrm{~mL}$ of methanol was added dropwise $30 \mathrm{~mL}(30 \mathrm{mmol})$ of a $1 \mathrm{M}$ sodium 
methoxide solution in methanol at $0{ }^{\circ} \mathrm{C}$. The reaction mixture was stirred for $2 \mathrm{~h}$ at $0{ }^{\circ} \mathrm{C}$, stored in refrigerator overnight, then diluted with water and extracted with ethyl acetate. The organic layer was washed with water and brine, dried over $\mathrm{MgSO}_{4}$ and the solvents were evaporated. The remaining residue was flash chromatographed on silica gel with petroleum ether (bp 40$\left.60{ }^{\circ} \mathrm{C}\right)$ /ethyl acetate (1:1) to give a crude mixture of intermediates $\mathbf{1 8}$ and $\mathbf{2 0}$, which was used for the next step without further purification.

To a solution of the crude mixture of $\mathbf{1 8}$ and $\mathbf{2 0}$ in $50 \mathrm{~mL}$ of toluene at reflux temperature, $150 \mathrm{mg}$ of $p-\mathrm{TsOH}$ was added in two portions. The reaction mixture was refluxed for $2.5 \mathrm{~h}$ in a Dean-Stark apparatus. The reaction mixture was diluted with toluene, washed with a saturated aqueous sodium bicarbonate solution and water, dried over $\mathrm{MgSO}_{4}$. The remaining residue (3.22 g) was flash chromatographed on silica gel with PE/EtOAc/pyridine (70:30:1) to give $1.98 \mathrm{~g}$ (75\%) of $\mathbf{2 2}$ as yellow oil. Crystallisation of $\mathbf{2 2}$ from ether gave colourless crystals with mp 70$71{ }^{\circ} \mathrm{C}$ (litt. $\left.71-73{ }^{\circ} \mathrm{C}^{5}\right)$. IR (neat): $2240(\mathrm{CN}), 1670(\mathrm{C}=\mathrm{O}) \mathrm{cm}^{-1} .{ }^{1} \mathrm{H}$ NMR $\left(\mathrm{CDCl}_{3}, 200 \mathrm{MHz}\right)$ : $1.34\left(3 \mathrm{H}, \mathrm{s}, \mathrm{CH}_{3}\right), 1.70-2.80(9 \mathrm{H}, \mathrm{m}), 5.80(1 \mathrm{H}, \mathrm{s}, \mathrm{CH}) .{ }^{13} \mathrm{C} \mathrm{NMR}\left(\mathrm{CDCl}_{3}, 50 \mathrm{MHz}\right): 18.69$ $\left(\mathrm{CH}_{3}\right), 26.01\left(\mathrm{CH}_{2}\right), 28.60\left(\mathrm{CH}_{2}\right), 32.97\left(\mathrm{CH}_{2}\right), 34.07\left(\mathrm{CH}_{2}\right), 40.79(\mathrm{CH}), 45.40(\mathrm{C}), 118.98(\mathrm{C})$, $123.25(\mathrm{CH}), 171.52(\mathrm{C}), 197.69(\mathrm{C})$.

4,7a-Dimethyl-5-oxo-2,3,5,6,7,7a-hexahydro-1H-indene-1-carbonitrile (23). To a stirred solution of $1.85 \mathrm{~g}(15 \mathrm{mmol})$ of cyanocyclopentanone 7 and $2.24 \mathrm{~mL}(22.5 \mathrm{mmol})$ of ethyl vinyl ketone $(\mathbf{E V K})$ in $20 \mathrm{ml}$ of dry diethyl ether, $1.85 \mathrm{~g}(16.5 \mathrm{mmol})$ of potassium tert-butoxide was added at $0{ }^{\circ} \mathrm{C}$. The reaction mixture was stirred for $2.5 \mathrm{~h}$ at $0{ }^{\circ} \mathrm{C}$, and then quenched with $1 \mathrm{M}$ $\mathrm{HCl}$. The mixture was diluted with ethyl acetate, and the organic solution was washed with water and brine, dried over $\mathrm{MgSO}_{4}$ and the solvents were evaporated. The residue (3.73 g) consisted of a crude mixture of several annulation products 21 , which was used in the next step without further purification.

To a stirred solution of the crude mixture of annulation products 21 in $50 \mathrm{~mL}$ of toluene at reflux temperature, $200 \mathrm{mg}$ of $p-\mathrm{TsOH}$ was added in two portions. The reaction mixture was refluxed for $4 \mathrm{~h}$ in a Dean-Stark apparatus. The reaction mixture was diluted with toluene, washed with a saturated aqueous sodium bicarbonate solution and water, dried over $\mathrm{MgSO}_{4}$ and the solvent was evaporated to give $3.86 \mathrm{~g}$ of crude $\mathbf{2 3}$. The further work up was performed in two ways:

A small portion of crude 23 was purified by bulb-to-bulb distillation to give $0.41 \mathrm{~g}$ (2.61 $\mathrm{mmol})(14 \%)$ of two isomers of 23. This mixture of isomers was flash chromatographed on silica gel with PE/EtOAc/pyridine (70:30:1) to give: $0.17 \mathrm{~g}(0.90 \mathrm{mmol})(6 \%)$ of the first eluted isomer, $0.10 \mathrm{~g}$ (3.5\%) of mixture of both isomers of 23 and $0.028 \mathrm{~g}$ of $(0.14 \mathrm{mmol})(0.9 \%)$ of the second eluted isomer.

The rest of the crude $\mathbf{2 3}$ was purified by flash chromatography as described above without bulb-to-bulb distillation to give: $1.093 \mathrm{~g}(5.8 \mathrm{mmol})(39 \%)$ of the first eluted isomer, probably the B-cyano compound and $0.61 \mathrm{~g}(21 \%)$ of second eluted isomer, probably the $\alpha$-cyano compound. The total yield of both isomers was $2.00 \mathrm{~g}(70 \%)$. 
The first eluted isomer of 23: IR (neat): $2236(\mathrm{CN}), 1662(\mathrm{C}=\mathrm{O}) \mathrm{cm}^{-1} .{ }^{1} \mathrm{H}$ NMR $\left(\mathrm{CDCl}_{3}, 200\right.$ MHz): 1.12-2.80 (m, 9H, 4xCH $2, \mathrm{CH}), 1.26\left(\mathrm{~s}, 3 \mathrm{H}, \mathrm{CH}_{3}\right), 1.61\left(\mathrm{~s}, 3 \mathrm{H}, \mathrm{CH}_{3}\right) ;{ }^{13} \mathrm{C} \mathrm{NMR}\left(\mathrm{CDCl}_{3}\right.$, $50 \mathrm{MHz}) \delta 11.29\left(\mathrm{CH}_{3}\right), 19.10\left(\mathrm{CH}_{3}\right), 26.49\left(\mathrm{CH}_{2}\right), 28.12\left(\mathrm{CH}_{2}\right), 32.99\left(\mathrm{CH}_{2}\right), 34.28\left(\mathrm{CH}_{2}\right)$, $41.26(\mathrm{CH}), 45.35$ (C), 119.21 (C), 129.00 (C), 164.70 (C), 197.24 (C). MS m/z (rel. abund.): 189 (M+, 91), 174 (17), 161 (100), 147 (90) 146 (27), 136 (14), 132 (23), 118 (18), 93 (16); HRMS calcd for $\mathrm{C}_{12} \mathrm{H}_{15} \mathrm{NO}$ 189.1154, found 189.1153 .

The second eluted isomer of 23: IR (neat): $2240(\mathrm{CN}), 1663(\mathrm{C}=\mathrm{O}) \mathrm{cm}^{-1} \cdot{ }^{1} \mathrm{H} \mathrm{NMR}\left(\mathrm{CDCl}_{3}\right.$, $200 \mathrm{MHz}): 1.11-2.89\left(\mathrm{~m}, 9 \mathrm{H}, 4 \mathrm{xCH}_{2}, \mathrm{CH}\right), 1.24\left(\mathrm{~s}, 3 \mathrm{H}, \mathrm{CH}_{3}\right), 1.70\left(\mathrm{~s}, 3 \mathrm{H}, \mathrm{CH}_{3}\right) ;{ }^{13} \mathrm{C} \mathrm{NMR}$ $\left(\mathrm{CDCl}_{3}, 50 \mathrm{MHz}\right) \delta 11.62\left(\mathrm{CH}_{3}\right), 22.87\left(\mathrm{CH}_{3}\right), 27.14\left(\mathrm{CH}_{2}\right), 28.32\left(\mathrm{CH}_{2}\right), 32.27\left(\mathrm{CH}_{2}\right), 33.00$ $\left(\mathrm{CH}_{2}\right), 42.00(\mathrm{CH}), 45.69(\mathrm{C}), 120.05(\mathrm{C}), 129.64(\mathrm{C}), 164.29$ (C), $197.13(\mathrm{C}) . \mathrm{MS} \mathrm{m} / \mathrm{z}(\mathrm{rel}$. abund.): 189 (M+, 95), 174 (19), 161 (65), 147 (100), 136 (13), 132 (23), 118 (15), 93 (16); HRMS calcd for $\mathrm{C}_{12} \mathrm{H}_{15} \mathrm{NO} 189.1154$, found 189.1157 .

\section{Acknowledgements}

The authors thank A. van Veldhuizen and B. van Lagen for NMR and IR spectroscopic data, and M.A. Posthumus for mass spectroscopic measurements. The authors gratefully acknowledge financial support from Organon International.

\section{References and Footnotes}

1. Duhamel P.; Dujardin G.; Hennequin L.; PoirierL-M. J. Chem. Soc., Perkin Trans. 1 1992, 387.

2. Jansen B.J.M.; Hendrikx C.C.J.; Masalov N.; Stork G.A.; Meulemans T.M.; Macaev F.Z.; de Groot Ae. Tetrahedron 2000, 56, 2075.

3. Nazarov N.; Zavyalov S.I. Bull. Acad.Sci. U.S.S.R., Div. Chem. Sci. (English transl.) 1957, 339.

4. Loewenthal H.J.E. Israel Journal of Chemistry 1966, 4, 31.

5. Inubushi Y.; Kikuchi T.; Ibuka T.; Tanaka K., I. Saji, Tokane K. Chem. Pharm. Bull. 1974, 22, 349.

6. Hynes J.; Overman L.E.; Nasser T.; Rucker P.V. Tetrehedron Letters 1998, 39, 4647.

7. Verstegen-Haaksma A.A.; Swarts H.J.; Jansen B.J.M.; de Groot Ae. Tetrahedron 1994, 50, 10037.

8. Dutcher J.S.; Macmillan J.G.; Heathcock C.H. J.Org. Chem. 1996, 41, 2663.

9. Macias F.A.; Anguilar J.M.; Molinillo J.M.G.; Rodrigues-Luis F.; Collado I.G.; Massanet G.M.; Fronczek F.R. Tetrahedron 2000, 56, 3409.

10. An J.; Wiemer D. J. Org. Chem. 1996, 61, 8775.

11. Jansen B.J.M., unpublished results.

12. Douglas G.H.; Graves J.M.H.; Hartley D.; Hughes G.A.; McLoughlin B.J.; Siddall J.; Smith H. J. Chem. Soc. 1963, 5072. 
13. Daniewski A.R.; Kowalczyk-Przewloka T. J. Org. Chem. 1985, 50, 2976.

14. Gaussian 98, Revision A.7, M. J. Frisch, G. W. Trucks, H. B. Schlegel, G. E. Scuseria, M. A. Robb, J. R. Cheeseman, V. G. Zakrzewski, J. A. Montgomery, Jr., R. E. Stratmann, J. C. Burant, S. Dapprich, J. M. Millam, A. D. Daniels, K. N. Kudin, M. C. Strain, O. Farkas, J. Tomasi, V. Barone, M. Cossi, R. Cammi, B. Mennucci, C. Pomelli, C. Adamo, S. Clifford, J. Ochterski, G. A. Petersson, P. Y. Ayala, Q. Cui, K. Morokuma, D. K. Malick, A. D. Rabuck, K. Raghavachari, J. B. Foresman, J. Cioslowski, J. V. Ortiz, A. G. Baboul, B. B. Stefanov, G. Liu, A. Liashenko, P. Piskorz, I. Komaromi, R. Gomperts, R. L. Martin, D. J. Fox, T. Keith, M. A. Al-Laham, C. Y. Peng, A. Nanayakkara, C. Gonzalez, M. Challacombe, P. M. W. Gill, B. Johnson, W. Chen, M. W. Wong, J. L. Andres, C. Gonzalez, M. Head-Gordon, E. S. Replogle, and J. A. Pople, Gaussian, Inc., Pittsburgh PA, 1998.

15. Another synthesis and the spectral characteristics for both isomers of 7 are described by: Cocker, W.; Grayson, D. H.; Shannon, P. V. R. J. Chem. Soc., Perkin Trans. 1 1995, 1153. 